\title{
Correction to: Assessment of post ischemic stroke infections
}

Mohammad A L-Bahy M. Gamal Reda', Ashraf E L-Sherbiny Abd EL-Hady², Hassan Kawashty Gad', Mohammad Abd E L-Hady M. Aboelmakarem ${ }^{1 *}$, Amir Abdel-Ghaffar Mohammady Nowar ${ }^{1}$ and Haytham Khalifa Hegazy ${ }^{1,2}$

\section{Correction to: Bull Natl Res Cent (2020) 44:56 https://doi.org/10.1186/s42269-020-00305-z}

Following publication of the original article (Gamal Reda et al. 2020), the authors identified an error in article title.

The incorrect article title is: 'Assessment, typo error on Author's response of Post Ischemic Stroke Infections'

The correct article title is: "Assessment of post ischemic stroke".

\section{Author details \\ ${ }^{1}$ Al-Azhar University, Cairo, Egypt. ${ }^{2}$ Internal Medicine, National Research}

Center, Giza, Egypt.

Published online: 27 July 2020

\section{Reference}

Gamal Reda et al (2020) Assessment of post ischemic stroke. Bull Natl Res Cent 44:56 https://doi.org/10.1186/s42269-020-00305-z

The original article can be found online at https://doi.org/10.1186/s42269020-00305-z

* Correspondence: Mohamedhady900@yahoo.com

The original article can be found online at https://doi.org/10.1186/s42269020-00305-z

${ }^{1}$ Al-Azhar University, Cairo, Egypt

Full list of author information is available at the end of the article

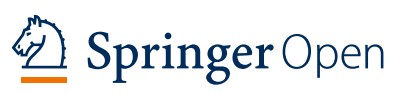

() The Author(s). 2020 Open Access This article is licensed under a Creative Commons Attribution 4.0 International License, which permits use, sharing, adaptation, distribution and reproduction in any medium or format, as long as you give appropriate credit to the original author(s) and the source, provide a link to the Creative Commons licence, and indicate if changes were made. The images or other third party material in this article are included in the article's Creative Commons licence, unless indicated otherwise in a credit line to the material. If material is not included in the article's Creative Commons licence and your intended use is not permitted by statutory regulation or exceeds the permitted use, you will need to obtain permission directly from the copyright holder. To view a copy of this licence, visit http://creativecommons.org/licenses/by/4.0/. 